out for this treatment. These cases occurred in men in middle life, and were afterward cured by male fern given after the usual prepuration of the patient.

A. J. STEVENS, M.D.

\section{Claudius Method of Preparing Catgut.}

$$
\text { OAKLAND, CAl., April 23, } 1903 .
$$

To the Editor:-After giving a faithful trial to the Claudius method of preparing gut according to the article of Senn in your issue of April 4, I find the gut worthless and brittle and absolutely dancrerous to use; it also stains the fingers and is too elastic. One good point it has in its favor, the infected gut gave no growth on bouillon after eight days' immersion in the rodin solution.

M. Lewis Farerson, M.D.

Chichigo, May l, 1903.

T'o the Editor:-The above failure is not due to the preparation of the catgut, but was the result of inferior catgut. We have had the same experience with inferior material, but with good catgut the result has always been ideal. 'In fact, the tensile strength has been greatly increased.

Emanuel J. Senn, M.D.

\section{Medical Organization.}

The New York State Medical Association.

County associations have recently been formed in the counties of Allegany, Lewis, Monroe, Tompkins and Wayne and there are several others which are about to be organized.

Henry County (Ala.) Medical Society.

At a meeting of this society held in Dothan, April 7, the members residing in Houston County withdrew and the society was reorganized, with Dr. Thomas T. Kennedy, Halesburg, president.

\section{Clay County (Neb.) Medical Society.}

The medical fraternity of the county met at Clay Center, April 20, at which a medical society was organized, with the following officers: President, Dr. O. P. Shoemaker, Clay Center; vice-president, Dr. John W. Thompson, Sutton; secretary, Dr. Adam R. Ray, Fairfield, and treasurer, Dr. Fordyce H. McCabe, Fairfield.

Houston County (Ala.) Medical Society.

On May 7 , the physicians residing in Houston County who withdrew from the Henry County Medical Society, met at Dothan, and organized a county society with Dr. John R. G. Howell, president; Dr. Henry Green, secretary; Dr. James L. Ellis, treasurer, and Dr. Mercer S. Davie, Jr., county health officer, all of Dothan.

\section{Clinton County (Ohio) Medical Society.}

This society met, April 29, at Wilmington, adopted the constitution recommended by the American Medical Association for county societies, and continued the following officers until the annual meeting in December: Dr. Allen T. Quinn, president; Dr. Eldorado Briggs, secretary, and Dr. George W. Wire, treasurer, all of Wilmington.

\section{Madison County (Ill.) Medical Society.}

The county organization was perfected at Alton, April 23, by the election of the officers of the Alton Medical Society to serve as officers for the county society for the remainder of the year. These oflicers are: 1)r. Frank Worden, North Alton, president; Dr. Waldo Fisher, Alton, vice-president; Dr. George E. Wilkinson, Alton, corresponding secretary; Dr. Homer W. Davis, Alton, recording secretary, and Dr. Westley W. Halliburton, Alton, treasurer.

\section{Allegany County (IN. Y.) Medical Association.}

The physicians of Allegany County met at Belmont recently and organized a county association, to be in affiliation with the New York State Medical Association, with an initial membership of 21. 'The officers elected are as follows: President, Dr. George H. Witter, Wellsville; vice-president, Dr. William o.
Congdon, Cuba, and secretary and treasurer, Dr. Horace $L$. Hulett, Alientown. Dr. Charles M. Post, Alfred, and Nathaniel H. Fuller, Friendship, were elected delegates to the state association.

\section{Societies.}

\section{COMING MEETINGS.}

American Academy of Medicine, Washington, D. C., May 11-12. American Therapeutic Society, Washington, D. C.., May 11-13. American Association of Genito-Urinary Surgeons, Washington, D. C., May 12-14. American Uermatological Association, Washington, D. C., May
12-14.

American Surgical Association, Washington. D. C., May 12.14 American Orthopedic Association. Washington, D. C., May 12-14. American Pediatric Society, Washington. D. C., May 1214.

Association of American Physicians, Washington, D. C. May 12-14. American Medico-X'sychological Association, Washington, D. C., May $12-1 \overline{5}$.

American Ophthalmological Assoclation, Washington, D. C., May 13-14.

Association of Military Surgeons of the United States, Boston, May 19-21.

New Hampshire Medical Society, Concord, May 21-22

North Dakota State Medical Society, Bismarck, May 21-22.

South Dakota State Medical Society, Mitchell, May 27-28.

Connecticut Medical Society. Hartford, May 27-28.

West Virginia State Medical Association, Charleston, May 26-28.

Indian Territory Medical Association, South McAlester, June 2-3.

Medical Society of the State of North Carolina, Hot Springs,

June 2.

Ohio State Medical Society. Dayton, June 3-5.

Rhode Island Medica I Society, Providence. June 4

Wisconsin State Medical Society, Milwaukee. June 3-5.

Maine Medical Association, Portland, June 3-5.

Indiana State Medical Society, Richmond, June 4-5.

Medical Society of Delaware, Dover. June 9.

Massachusetts Medical Society, Boston. June 9-10.

Michigan State Medical Society, Detroit, June 11-12.

Minnesota State Medical Society, St. Paul. June 17.

Medical Association of Montana, Helena. June 17-18

Medical Society of New Jersey, Asbury Park, June 23-25.

Columbia (S. C.) Medical Society.-At the regular meeting, April 6, Dr. Lawrence B. Owens was elected president; Dr. D. Strother Pope, vice-president, and Dr. Mary R. Baker, secretary-treasurer.

Louisville Medical and Surgical Society.-This society was organized April 20, with Dr. R. Lindsay Ireland, president; Dr. Frank J. Kiefer,, vice-president; Dr. Harry A. Davidson, secretary, and Dr. W. Jennings, treasurer.

American Medico-Psychological Association.-This association, formerly known as the Association of Medical Superintendents of American Institutions for the Insane, will hold its fifty-ninth annual meeting in Washington, May 12, 13, 14 and 15 .

South Idaho District Medical Association.-At the annual meeting held at Boise, April 8 and 9, Dr. Lewis C. Bowers, Boise, was elected president; Dr. J. S. Stewart, Boise, vicepresident, and Dr. Hubert A. Castle, Pocatello, secretarytreasurer.

Hampden District (Mass.) Medical Society.-The annual meeting was held in Springfield, Mass., April 2l. Dr. James W. Hannum, Ludlow, was elected president; Dr. Angelo O. Squier, Springfield, president, and Dr. James E. Marsh, Springfield, secretary and treasurer.

Whiteside County (Ill.) Medical Society.-At the annual meeting held in Morrison, April 15, Dr. James A. Nowlen, Morrison, was elected president; Dr. Charles E. Parker, Sterling, vice-president; Dr. Perry F. Purdue, Lyndon, secretary, and Dr. John F. Keefer, Sterling, treasurer.

Cecil County (Md.) Medical Society.-The annual meeting. was held at Elkton, April 16, and the following officers were elected: Dr. David L. Gifford, Zion, president; Dr. George M. Stump, Perryville, vice-president; Dr. Howard Bratton, Elkton, secretary, and Dr. John H. Jamar, Elkton, treasurer.

Northeast Missouri Medical Association.-At the annual meeting held in Memphis, April 14, Dr. Frank B. Hiller, Kahoka, was elected president; Dr. James B. Bridges, Downing, vicepresident, and Dr. E. E. Parrish, Memphis, secretary-treasurer. The next meeting will be held in Kahoka, in October.

Brainerd District (Ill.) Medical Society.-The annual meeting was held in Lincoln, April 23. Dr. Algernon M. Sargent, Lincoln, was elected president; Dr. Irving Newcomer, Petersburg, vice-president; Dr. Harry S. Oyier, Lincoln, secretary; Dr. 